\title{
Warm-season grass establishment as affected by post- planting atrazine application
}

\author{
C.C. BAHLER, L.E. MOSER, T.S. GRIFFIN, AND K.P. VOGEL
}

\section{Abstract}

Atraxine [6-chloro-N-ethyl-N'-(1-methylethyl)-1,3,5-triazine-2, 4-diamine] provides effective weed control during big bluestem (Andropogon gerardii Vitman) and switchgrass (Panicum virgatum L.) establishment. However, most other desirable warmseason grasses are susceptible to atrazine injury at establishment. The objective of this study was to determine if atrazine application after seeding would affect susceptible warm-season grass establishment. Big bluestem, switchgrass, indiangrass [Sorghastrum nutans (L.) Nash], sideonts grama [Bouteloud curtipendula (Michx.) Torr.], and little bluestem [Schizachyrium scoparium (Michx.) Nash] were seeded into greenhouse flats or field plots and $2.2 \mathrm{~kg}$ a.i. atrazine/ha applied at 0 (atrazine control), 7, 14, or 21 days after planting. An untreated control was used also. In greenhouse experiments, indiangrass and sideoats grama plant survival increased when atrazine applications were delayed. Switchgrass, big bluestem, and little bluestem plant survival was not affected by atrazine application. Field studies were conducted in 1983, 1985, and 1986 using the same soil type, grass species, and application periods as the greenhouse study. Delaying atrazine application 7 or more days after planting generally favored survival of indiangrass and sideoats grama. Big bluestem, switchgrass, and little bluestem were not affected by atraxine treatment. Delaying the application of atrazine may favor the survival of atrazine sensitive species. However, further research needs to be conducted on various soil types and environmental conditions before this can be a recommended practice.

Key Words: 6-chloro-N-ethyl-N'-(1-methylethyl)-1,3,5-triazine2,4-diamine, Andropogon gerardit Vitman, Panicum virgatum L., Sorghastrum nutans (L.) Nash, Bouteloua curtipendula (Michx.) Torr., Schizachyrium scoparium (Michx.) Nash

Atrazine, [6-chloro-N-ethyl-N'-(1-methylethyl)-1,3,5,-triazine-2, 4-diamine], controls annual broadleaf and grassy weeds in switchgrass (Panicum virgatum L.) and big bluestem (Andropogon gerardii Vitman) seedings because these grasses are atrazine tolerant (Bahler et al. 1984, McCarty 1976, Kern 1976, Martin et al. 1982). Samson and Moser (1982) established sod-seeded switchgrass in eastern Nebraska pastures dominated by Kentucky bluegrass ( Poa pratensis $\mathrm{L}$.) with applications of atrazine and paraquat (1,1'-dimethyl-4,4'-bipyridinium ion).

Establishment of other desirable warm-season grass seedlings with atrazine has been a problem because of susceptibility to atrazine injury. Indiangrass [Sorghastrum nutans (L.) Nash] stand and yield were reduced; sand lovegrass [Eragrostis trichodes (Nutt.) Wood] and sideoats grama [Bouteloua curtipendula (Michx.) Torr.] seedlings were killed by atrazine (Martin et al. 1982, Bahler et al. 1984). Delaying the atrazine application until sorghum [Sorghum bicolor (L.) Moench] was $15 \mathrm{~cm}$ tall controlled weeds without injury to the plant (Wiese and Rea 1962).

\footnotetext{
Authors are statistical analyst/programmer, SUPELCO Inc., Bellefont. Penn. 16823; professor, Department of Agronomy, University of Nebraska, Lincoln 68583; research assistant, Department of Agronomy, Michigan State University, East Lansing 48824; and supervisory research geneticist USDA/ARS, Deparment of Agroning 48824 ; and supervisory research geneticist

Published with the approval of the Director, Nebraska Agric. Res. Div., Journal Series Paper No. 8793

Manuscript accepted 8 March 1990
}

The objective of this study was to determine whether delaying atrazine application to after seeding would decrease the amount of injury sustained by susceptible warm-season grass species such as indiangrass, sideoats grama, and little bluestem [Schizachyrium scoparium (Michx.) Nash] sufficiently for adequate stand establishment.

\section{Materials and Methods}

\section{Greenhouse Study}

One-year-old seedlots of 'Pawnee' big bluestem, 'Pathfinder' switchgrass, 'Oto'indiangrass, 'Butte' sideoats grama, and 'Camper' little bluestem were used. Seeds were planted in 0.6 by 0.3 by $.08-\mathrm{m}$ flats containing $15 \mathrm{~kg}$ of a 2:1 soil-sand mixture. The soil was a Sharpsburg silty clay loam (Typic Argiudoll). The seed were planted in single rows $0.5 \mathrm{~m}$ in length at a rate of 131 pure live seeds (PLS) per meter of row. The flat were subirrigated the day before planting. Watering after planting occurred from the top to ensure atrazine presence in the rooting zone and to simulate field conditions.

The flats were sprayed with an atrazine-distilled water solution containing $6.06 \mathrm{mg} / \mathrm{L}$ atrazine to obtain a $2 \mathrm{mg} / \mathrm{kg}(2.2 \mathrm{~kg} / \mathrm{ha})$ concentration of atrazine in the soil. Single applications of atrazine solution were made to whole flats 0 (atrazine control), 7, 14, or 21 days after planting. In addition, an untreated control receiving no atrazine was also included. Air temperature was approximately $27^{\circ} \mathrm{C}$ during the day and approximately $15^{\circ} \mathrm{C}$ at night during the study. Additional fluorescent lighting was provided producing a 12-hour day length.

A split-plot treatment arrangement with 4 replications was used with time of atrazine application as the whole plot and species as the subplot. The study was repeated. An analysis of variance was performed on the number of plants present 49 days after planting. Separate analyses were performed on the 2 runs and Bartlett's test was used to determine whether the variances from the 2 runs were homogeneous (Steele and Torrie 1980). Bartlett's test was nonsignificant, indicating no evidence for nonhomogeneity, and the analysis of variance was performed on the combined data sets. Means were separated using Fisher's Protected L.S.D. (Steele and Torrie 1980).

\section{Field Studies}

The field plots were located at the University of Nebraska Research and Development Center near Mead, Nebr., on a Sharpsburg silty clay loam (Typic Argiudoll). A conventional seedbed was prepared by both discing and harrowing the soil before fumigation. Plots were fumigated with methyl bromide to reduce the weed seed viability in the soil. The plots were fumigated for $\mathbf{6 4}$ hours before removal of the plastic and then allowed to equilibrate for 12 days to ensure complete methyl bromide dissipation.

'Pawnee' big bluestem, 'Pathfinder' switchgrass, 'Oto' indiangrass, 'Butte' sideoats grama, and 'Camper' little bluestem were planted on 25 May 1983 (day 145) at a rate of 131 PLS per meter of row in single $6.1-\mathrm{m}$ rows. The rows were spaced $0.6 \mathrm{~m}$ apart. Atrazine was applied at $2.2 \mathrm{~kg}$ a.i. atrazine/ ha at 0 (day of planting), 7,14 , or 26 days after planting. An untreated control also was 
included. A surfactant was not used in order to minimize foliar uptake by any emerged seedlings.

Tiller frequency was recorded 60 days after planting ( 34 days after the last application date). The number of 5-cm intervals of a 1 $m$ rod occupied by at least 1 seedling was recorded. Measurements were taken at 3 random locations within the row after excluding 0.3 $\mathrm{m}$ from each end. The 3 measurements were averaged and percent frequency calculated. Rainfall was measured during the growing period.

The experiment was arranged in a split-plot design. The whole plot was time of atrazine application, and the subplot was species. The study had 4 replications with the analysis of variance being conducted on the percent frequency data. Means were separated using Fisher's Protected L.S.D.

Similar studies were conducted in 1985 and 1986 using different seedlots of the same species and cultivars. Methyl bromide was not used to kill weed seed in the soil. Similar application intervals were used. The experimental design each year was a split-plot with 4 replications. The whole plot was the time of atrazine application, and the subplot was species.

Seeds were planted 28 May 1985 and 14 May 1986 into a conventionally prepared seedbed. Atrazine was applied 2, 9, 16, or 28 days after planting in 1985 and $0,7,14$, or 21 days after planting in 1986 . Stand frequency data were collected 56 and 71 days after planting (28 and 50 days after the last application date) for 1985 and 1986, respectively. Weed yields were determined on 28 July 1986, by cutting a $0.6 \times 5.5-\mathrm{m}$ area in each plot to a height of $2.5 \mathrm{~cm}$. Subsamples were oven dried and dry matter yields calculated. An analysis of variance was performed on the percent frequency in 1985 and on the percent frequency and weed yields in 1986. Means were separated with a Fisher's Protected L.S.D.

\section{Results and Discussion}

\section{Greenhouse Study}

All species emerged 5 to $\mathbf{1 0}$ days after planting. There was a significant interaction among the atrazine application dates and species. The number of big bluestem, little bluestem, and switchgrass plants per $0.5 \mathrm{~m}$ of row was not affected by atrazine application at any date (Table 1), although little bluestem had fewer plants

Table 1. The effect of applying atraxine $0,7,14$, or 21 days after planting on the number of plants in $0.5 \mathrm{~m}$ of row 49 days after planting under greenhouse conditions.

\begin{tabular}{llcccc}
\hline \hline $\begin{array}{l}\text { Atrazine } \\
\text { application }\end{array}$ & $\begin{array}{c}\text { Big } \\
\text { bluestem }\end{array}$ & $\begin{array}{c}\text { Little } \\
\text { bluestem }\end{array}$ & $\begin{array}{c}\text { Switch- } \\
\text { grass }\end{array}$ & $\begin{array}{c}\text { Indian- } \\
\text { grass }\end{array}$ & $\begin{array}{c}\text { Sideoats } \\
\text { grama }\end{array}$ \\
\hline & $\ldots \ldots \ldots$ & $\ldots$ & plant number & $\ldots \ldots$ & $\ldots$ \\
Untreated control & $54 \mathrm{a}$ & $19 \mathrm{a}$ & $54 \mathrm{a}$ & $43 \mathrm{a}$ & $29 \mathrm{a}$ \\
Atrazine control & $54 \mathrm{a}$ & $9 \mathrm{a}$ & $53 \mathrm{a}$ & $25 \mathrm{~b}$ & $6 \mathrm{~b}$ \\
7 days & $53 \mathrm{a}$ & $22 \mathrm{a}$ & $54 \mathrm{a}$ & $37 \mathrm{ab}$ & $16 \mathrm{ab}$ \\
14 days & $54 \mathrm{a}$ & $19 \mathrm{a}$ & $49 \mathrm{a}$ & $33 \mathrm{ab}$ & $27 \mathrm{a}$ \\
21 days & $51 \mathrm{a}$ & $12 \mathrm{a}$ & $49 \mathrm{a}$ & $33 \mathrm{ab}$ & $25 \mathrm{a}$ \\
\hline
\end{tabular}

-Mean with the same letter are not significantly different at the $5 \%$ level using Fisher's protected L.S.D.

in all treatments than big bluestem or switchgrass.

Indiangrass and sideoats grama had a lower plant number in the atrazine treated flats at seeding compared to untreated plots (Table 1). When atrazine was applied 7,14 , and 21 days after planting, the number of plants did not differ from the untreated control for indiangrass and were not significantly higher than that from flats where atrazine was applied at seeding. Sideoats grama had an increase in plant numbers in the flats treated on 14 or 21 days after planting compared to flats where atrazine was applied at seeding and the number of plants present were similar to those in the untreated control (Table 1). Plant numbers in the flats treated 7 days after planting were not different from either the untreated flats or flats receiving atrazine at seeding.

\section{Field Studies}

In 1983, grasses did emerge until after the 7-day treatment. At the 14-day application, grasses were just beginning to emerge after the $2.4 \mathrm{~cm}$ rainfall on day 11 . At the last application date, 26 days after planting, the grasses were all emerged and some had several leaves. In 1983, there was a significant interaction among application dates and species. Switchgrass, big bluestem, and little bluestem all had no significant differences between the untreated control and the 4 atrazine application dates (Fig. 1). There was a decrease in stand frequency in indiangrass and sideoats grama
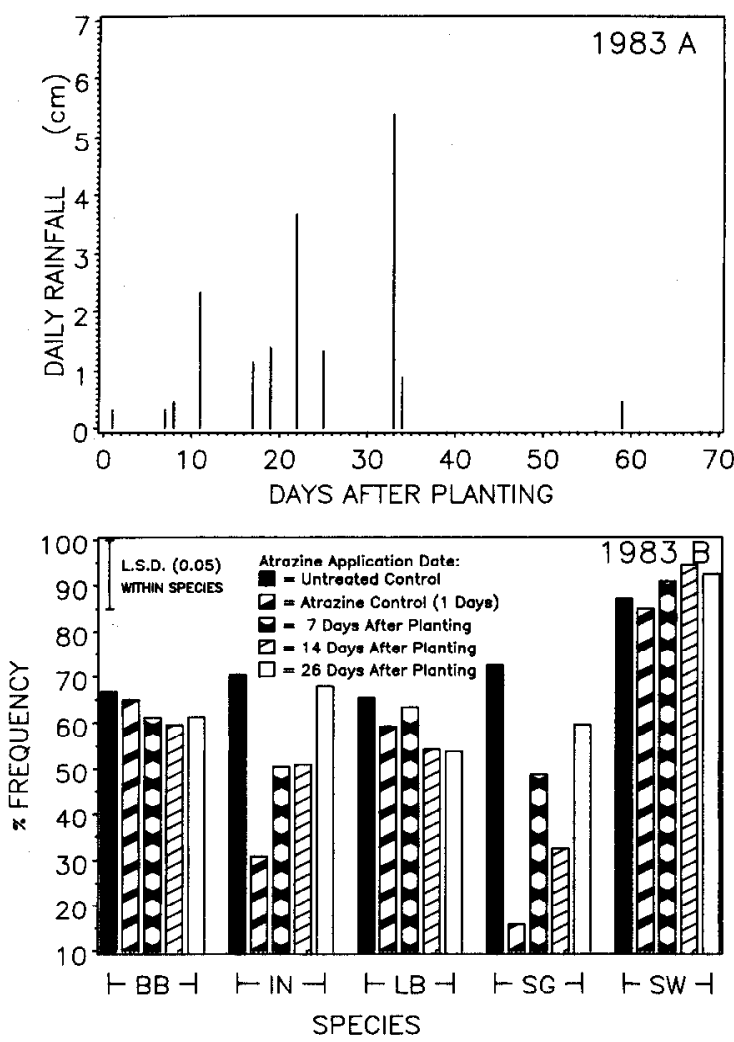

Fig. 1. Rainfall (1983A) and the effect of atraxine application date on the percent frequency (1983B) within big bluestem (BB), indiangrass (IN), little bluestem (LB), sideoats grama (SG), and switchgrass (SW) during 1983.

where atrazine was applied at seeding (Fig. 1) and indiangrass and sideoats grama frequencies were significantly greater at the 7-, 14-, and 26-day application times compared to plots where atrazine was applied at planting. Stands of both indiangrass and sideoats grama with the 26-day treatment were equivalent to those of the untreated control. Stands were considered good where the frequency is $30 \%$ or more (Samson and Moser 1982). The stands for big bluestem, little bluestem, and switchgrass were excellent with 50 to $95 \%$ frequency. Only sideoats grama stands where atrazine was applied 1 day after seeding were unsatisfactory.

In 1985 , over $1 \mathrm{~cm}$ of rain fell in the 2 days following seeding before the first (atrazine control) application could be made. The seed and surrounding soil were thoroughly wet so imbibition began before any atrazine was present. The grasses began to emerge by the second application date ( 9 days after planting) and switchgrass had the greatest amount of emergence. At the 16-day application, all grasses were emerged but there was little leaf area. By the 28-day 
application, many grasses of all the species had developed several collared leaves. In 1985 there was no significant interaction among the atrazine application dates and species. Since the first application was delayed by 2 days due to rain, plant frequency in atrazine susceptible species was not depressed as it was when atrazine was applied immediately after planting (Figs. 1 and 2). Imbibition of the seed occurred before atrazine was present. When sufficient water is present, rapidly imbibing water will bring atrazine with it (Davis et al. 1965, Hocombe 1968). In the 1983 field study and in
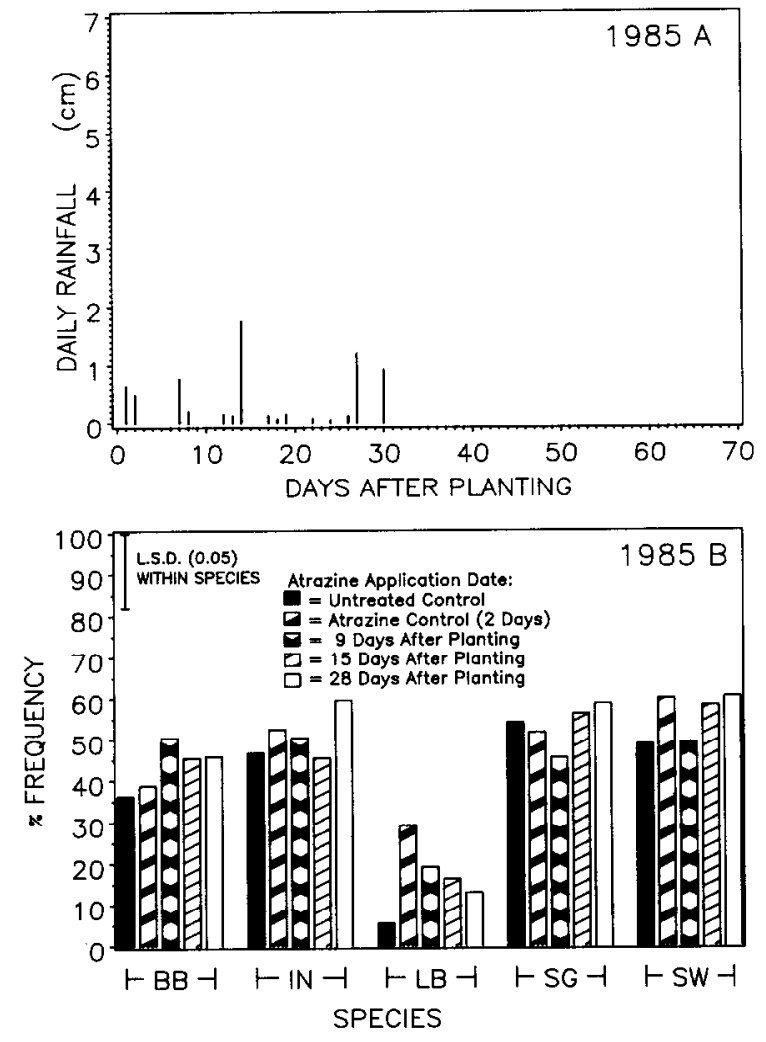

Fig. 2. Rainfall (1985A) and the effect of atrazine application date on the percent frequency (1985B) within big bluestem (BB), indiangrass (IN), little bluestem (LB), sideouts gramm (SG), and switchgrass (SW) during 1985.

the 2 greenhouse studies, atrazine susceptible species had emergence equal to untreated soil after imbibition, seed coat cracking, and initial atrazine uptake had occurred.

In 1986, the first application was made immediately after planting. Two days after planting there was over a $3.0 \mathrm{~cm}$ rainfall event which initiated imbibition. Most grasses were not emerged until the 14-day application date. By the 21-day application data, several small rains had occurred. Most grasses were emerged but were mostly at the 1 to 2 leaf stage. In 1986, there was a significant interaction between atrazine application date and species. Low emergence of indiangrass and little bluestem was attributed to low seed vigor or dormancy of the seedlots used since emergence from control plots was low (Fig. 3). Switchgrass and big bluestem were not significantly affected by the application date and excellent stands resulted. Atrazine at all application dates significantly lowered sideoats grama frequency compared to untreated plots. The only satisfactory stand of sideoats grama was on the untreated control plots, although with 21 days of delay there was a significant increase in seedling frequency compared to the atrazine control and the 7-day treatment.

In 1986, all atrazine applications reduced weed growth (Table 2)
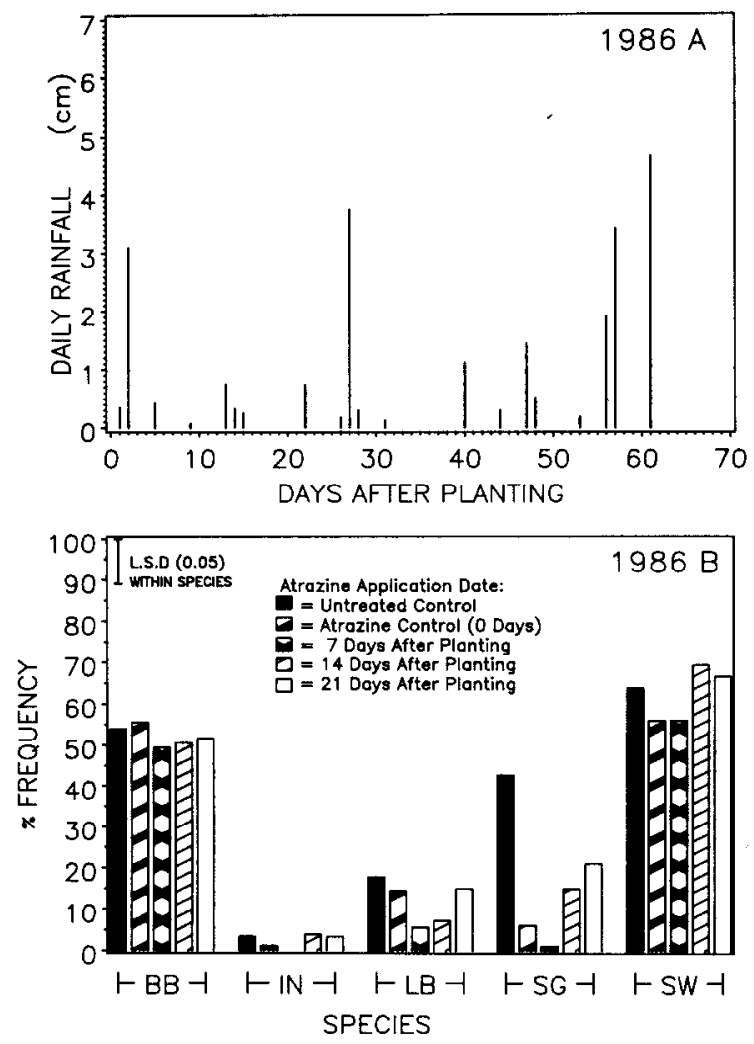

Fig. 3. Rainfall (1986A) and the effect of atrazine application date on the percent frequency (1986B) within big bluestem (BB), indiangrass (IN), little bluestem (LB), sideoats grama (SG), and switchgrass (SW) during 1986.

although there was a trend towards higher weed yields as atrazine applications were delayed. The competitive ability of the weed population as measured by weed yields was reduced even with a 21-day delay in atrazine application. Pigweed (Amaranthus retroflexus L.), Lambsquarters (Chenopodium album L.), green foxtail [Setaria viridis (L.) Beauv], and seedling smartweed (Polygonum pensylvanicum $\mathrm{L}$.) were the major weed species. All species were

Table 2. The effect of atrazine application date on weed dry matter yields 28 July 1986.

\begin{tabular}{lc}
\hline \hline Atrazine application date & Weed yield \\
\hline & $\mathrm{kg}$ dry wt/ha \\
Untreated control & $1509 \mathrm{a}^{*}$ \\
At Planting (0 days) & $269 \mathrm{~b}$ \\
7 days & $204 \mathrm{~b}$ \\
14 days & $348 \mathrm{~b}$ \\
21 days & $614 \mathrm{~b}$ \\
\hline
\end{tabular}

* Means with the same letter are not significantly different at the $5 \%$ level using Fisher's protected L.S.D.

reduced by the atrazine applications. Green foxtail was present only on the plots that were not treated with atrazine. Atrazine did not increase competition from grass weeds as would be the situation with 2,4-D.

\section{Conclusions}

Based on both field and greenhouse studies, post-emergence atrazine application from 1 to 3 weeks after seeding shows potential for producing satisfactory stands of atrazine sensitive warmseason grasses on fine textured soils with high organic matter. 
Little bluestem appears to have a moderately high level of atrazine tolerance when atrazine is applied at seeding time, which confirms work by Bahler et al. (1984). Even with a species very sensitive to atrazine like sideoats grama, improved stands occurred when atrazine was not present in early stages of imbibition and germination. Since complete weed control is not necessary, delaying application of atrazine in warm-season grass establishment may allow grasses with marginal atrazine tolerance to be established.

\section{Literature Cited}

Bahler, C.C., K.P. Vogel, and L.E. Moser. 1984. Atrazine tolerance in warm-season grass seedlings. Agron. J. 76:891-895.

Davis, D.E., J.V. Gramlich, and H.H. Funderbunk. 1965. Atrazine absorption and degradation by corn, cotton, and soybeans. Weeds 13:252-255.
Hocome, S.D. 1968. The uptake of atrazine by germinating seeds of turnip (Brassica rapa L.). Weed Res. 8:68-71.

Kern, C.L. 1976. The use of atrazine as an aid in switchgrass establishment. Proc. North Central Weed Control Conf. 31:98-99.

Martin, A.R., R.S. Moomaw, and K.P. Vogel. 1982. Warm-season grass establishment with atrazine. Agron. J. 74:916-920.

McCarty, M.K. 1976. Weed control as an aid to warm-season grass establishment. Proc. North Central Weed Control Conf. 31:99-100.

Samson, J.F., and L.E. Moser. 1982. Sod-seeding of perennial grasses into eastern Nebraska pastures. Agron. J. 74:1055-1060.

Steel, R.G.D., and J.H. Torric. 1980. Principles and procedures of statistics. McGraw Hill Co., Inc. New York. pp. 471-472.

Wiese, A.F., and H.E. Rea. 1962. Treating irrigated grain sorghum with pre-emergence herbicides. Crop Sci. 2:29-32. 